\title{
Structure of a Tropical Squall Line Observed in the Western Tropical Pacific during MONEX
}

\author{
by \\ Masahito Ishihara and Zenji Yanagisawa \\ Meteorological Research Institute, Tsukuba, Japan
}

(Received Nov. 17, 1981; Revised June 30, 1982)

\begin{abstract}
This paper describes an analysis of the structure of a tropical squall line by the use of radar, satellite, and upper air sounding data. The observation was made in the west of the western tropical Pacific during Summer MONEX in 1979. The results of the analysis were compared with the structure of tropical squall lines observed by other authors.

The squall line in this study showed a significantly organized mesoscale structure; that is, cumulus-scale convections and organized convections were combined within it. The existence of organized convection was the particular feature of this squall line. Anvil clouds covered these convectoins and extended back from the leading edge for more than $200 \mathrm{~km}$. The line-shaped leading edge of the squall line propagated at a speed larger than that of ambient winds. Some portions of the leading edge were not dissipated and grew into organized convections, which maintained size and intensity for several hours.

The squall line was formed in the boundary region between the monsoon southwesterly and the trade wind easterly in the lower troposphere. Just before the squall line was formed, a relatively large positive vorticity had existed in the middle and lower troposphere, and a large divergence of air above $400 \mathrm{mb}$ and moderate convergence below $400 \mathrm{mb}$. The overturning of the atomosphere was found by upper sounding data, and the moist static energy located in the lower troposphere ahead of the squall line was thought to be an energy source of the formation of the squall line.

Several common properties were seen in tropical squall lines in our case and in other tropical regions, but the cloud structure of the squll line in our case should be discussed three-dimensionally because of the existence of the organized convections.
\end{abstract}

\section{Introduction}

The tropical squall line has been observed at several places in the tropics, that is, in the West Africa (Hamilton and Archbold, 1945), in the Mid-Pacific (Zipser, 1969), and in the Caribbean Sea (Betts et al., 1976). Zipser (1977) investigated the detailed structure of tropical squall line in the Caribbean Sea using airplane data, and Houze (1977) used quantitative radar and upper sounding data during GATE.

Zipser defined that the squall line is active cumulonimbus clouds organized in linear fashion and that the squall system is the aggregate of phenomena associated with squall lines and its trailing anvil cloud. He pointed out that the characteristics of the squall system were large propagation speed and two types of downdraft embedded in the squall system; the convective-scale downdraft existed at the front part of the squall line, and the mesoscale downdraft occupied the light rain area beneath the widely spread anvil clouds in the rear part of the squall system. In this paper, the term tropical squall line 
refers to a kind of mesoscale cloud system in the tropics. This cloud system consists of an intense rain area showing line- or arc-shape and a light rain area occupying a large part of the cloud system. Further, the term leading edge refers to the line- or arc-shaped rain area located in the front part of the squall line.

A comparison of the structure of tropical squall lines with that of midlatitude squall lines was carried out by Ogura and Liou (1980). They presented the thermodynamic and kinematic structure of the squall line that occurred in Oklahoma. They pointed out that many characteristics of midlatitude squall line were quite similar to those typical of the tropical squall lines, especially those of the thermodynamic structure in the region below the anvil cloud. They also said that an understanding of the dynamics of the squall line would be increased by observing both midlatitude and tropical squall lines.

The purposes of this paper are

1) to describe the structure of a tropical squall line observed in the western tropical Pacific during summer MONEX (Monsoon Experiment) in 1979 using radar, satellite and upper sounding data, and

2) to campare the structure of the squall line in our case with squall lines observed in other tropical regions, especially in GATE and the Caribbean Sea, and to confirm whether the characteristics of squall lines that have been found in this decade are common in the tropics or not.

\section{Data}

\subsection{Data obtained on board the Keifu-maru}

During the summar MONEX in 1979, the ship Keifu-maru was located at $2^{\circ} \mathrm{N}$ and $130^{\circ} \mathrm{E}$ in the tropical Pacific as shown in Fig. 1, and various data were obtained as shown below. The MONEX/FGGE Data Report (1980) published from the Meteorological Research Institute comprises almost all these data.

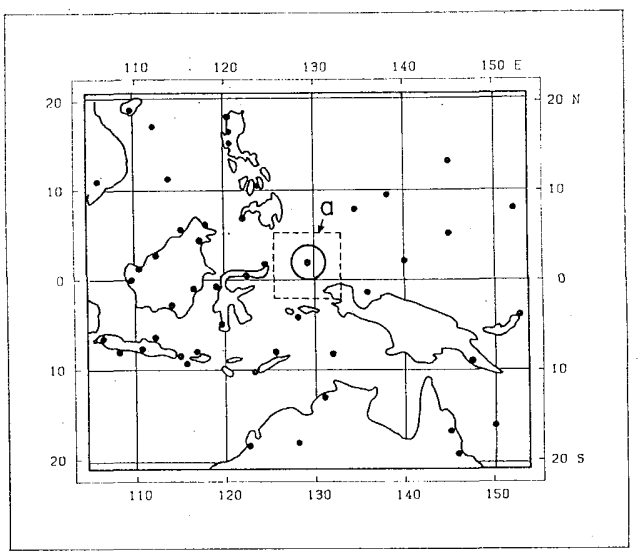

Fig. 1. Observational domain of the Keifu-maru radar (circle) and network of upper wind sounding (dots) on 16 May 1979. Divergence in Fig. 4 are calculated in the square $a$ enclosed by dashed line.

\section{a. Radar data}

The characteristics of the weather radar aboard the Keifu-maru are shown in Table 1. The observations of three-dimensional PPI scan and four-gain-level PPI/RHI scan were alternated. Three-dimensional (3-D) observation that consisted of a series of PPI scan in 14 antenna elevation angles ranging from $0.0^{\circ}$ to $20.0^{\circ}$ was made once every $20 \mathrm{~min}$ utes. Four-gain-level PPI/RHI observation was made every 3 minutes between $3-\mathrm{D}$ observations. Decreasing the gain of the IF amplifier of the radar receiver in four steps from $-101 \mathrm{dBm}$ of minimum detectable signal to $-70 \mathrm{dBm}$ using a gain-level slicer, PPI scans of $0.0^{\circ}$ elevation angle and RHI scans were made. The reflectivity data obtained from these two kinds of observations were recorded on $35 \mathrm{~mm}$ cinefilm.

Table 1. Characteristics of the weather radar on board the Keifu-maru.

$\begin{array}{ll}\text { Wave length } & 5.66 \mathrm{~cm} \\ \text { Maximum peak power } & 250 \mathrm{kw} \\ \text { Beam width } & 1.7^{\circ} \\ \text { Minimum detectable signal } & -101 \mathrm{dBm} \\ \text { Pulse duration } & 2.15 \mu \mathrm{s} \\ \text { Pulse repetation frequency } & 260 \mathrm{~Hz} \\ \text { Maximum range } & 400 \mathrm{~km}\end{array}$


b. Surface data

Surface observation including wind, rainfall amount, dry and dew-point temperature measurements was made continuously on board the Keifu-maru. The size distribution of raindrops was measured by the filter paper technique.

c. Upper air soundsng data

Upper air soundings were made at sixhour intervals on the Keifu-maru. The data at $00 \mathrm{GMT}$ and $12 \mathrm{GMT}$ include wind, temperature and humidity measurements. The data at 06 GMT and 18 GMT include wind measurement. The lower tropospheric radiosonde (LTS) measured dry and wet-bulb temperature for every $10 \mathrm{mb}$ up to $940 \mathrm{mb}$ and for $30 \mathrm{mb}$ up to $700 \mathrm{mb}$ at nearly four-hour intervals.

\subsection{FGGE level III-B data}

The FGGE level III-B data sets were prepared at ECMWF (European Centre for Medium Range Weather Forecasts), and provide us with results of objective analysis of geopotential height, wind, and vapor content at 15 standard pressure levels on every 1.875 degree latitude/longitude grid at 00 and 12 GMT.

\subsection{Satellite data}

The Geostationary Meteorological Satellite (GMS) positioned at $140^{\circ} \mathrm{E}$ on the equator provides us with 2-channels data in visible $(0.5-0.7 \mu \mathrm{m})$ and infrared $(10.5-12.5 \mu \mathrm{m})$ regions. The horizontal resolutions of the two kinds of radiometers are $1.25 \mathrm{~km}$ in visible channel and $5.0 \mathrm{~km}$ in infrared channel respectively.

\section{Large-scale environment and general view of the squall line}

\subsection{Method of analysis}

The large-scale situation was examined by use of the FGGE III-B data sets and GMS satellite pictures.

The relative vorticity $\zeta$ and stream function $\phi$ are respectively expressed by

$$
\zeta=k \cdot \nabla \times V
$$

and

$$
\nabla^{2} \psi=\zeta \text {, }
$$

where $\boldsymbol{V}$ is the horizontal wind. Yanai and Nitta (1967) showed that the rotational part of the wind in the tropics is generally much larger than the divergent part. For this reason, we examined the large-scale wind field with using stream function $\phi$.

\subsection{Large-scale flow}

The distributions of stream function $\psi$ at 200,500 and $850 \mathrm{mb}$ on 16 May are shown in Fig. 2. At $200 \mathrm{mb}$ (Fig. 2-a), in the Northern Hemisphere a large anticyclonic circulation was found west of $140^{\circ} \mathrm{E}$. A cyclonic flow existed east of $145^{\circ} \mathrm{E}$ and reached the MidPacific trough that was located from near $180^{\circ} \mathrm{E}$ to $140^{\circ} \mathrm{W}$. In the Southern Hemisphere, a strong westerly jet was seen south of $15^{\circ} \mathrm{S}$. Two anticyclonic circulations were seen over the New Guinea and west of $115^{\circ} \mathrm{E}$. These features of the large-scale flow at $200 \mathrm{mb}$ appeared almost stationary.

The motion field at $850 \mathrm{mb}$ (Fig. 2-c) was not so stationary as that a $200 \mathrm{mb}$, but its characteristic features did not much changed. In the Northern Hemisphere, the boundary between the monsoon southwesterly and the trade wind easterly lay near $130^{\circ} \mathrm{E}$. The Keifu-maru was located in this boundary region. In the Southern Hemisphere, an anticyclonic circulation that came from the polar high over Australia was seen south of $10^{\circ} \mathrm{S}$. The zonal belt of weak winds with speeds less than $3 \mathrm{~m} / \mathrm{s}$ extended from near the equator to $10^{\circ} \mathrm{S}$.

\subsection{Relative vorticity field}

Fig. 3 shows the time sequence of distributions of the relative vorticity at $700 \mathrm{mb}$ in the zone between $10^{\circ} \mathrm{N}$ and $5^{\circ} \mathrm{S}$. There were two regions of positive vorticity along near $5^{\circ} \mathrm{N}$ latitude on 13 May. One of them (A in Fig. 3) existed at near $130^{\circ} \mathrm{E}$ from 13 to 18 May. The other (B in Fig. 3) was located at $148^{\circ} \mathrm{E}$ on 13 May and moved westward in the trade wind. Two regions were merged into a region of large positive vorticity of 


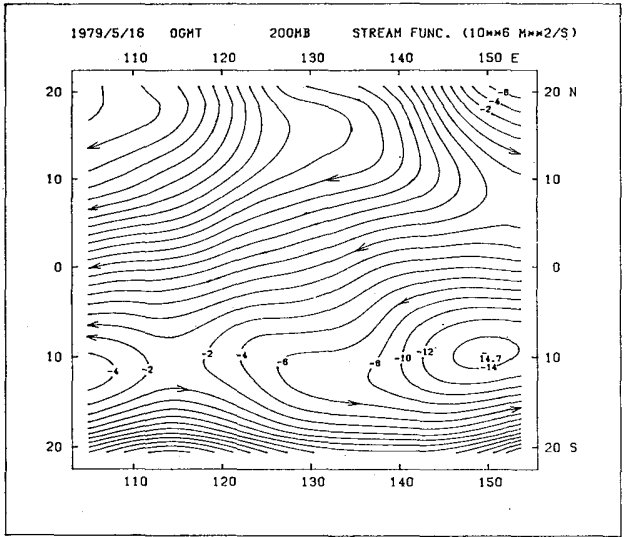

(a)

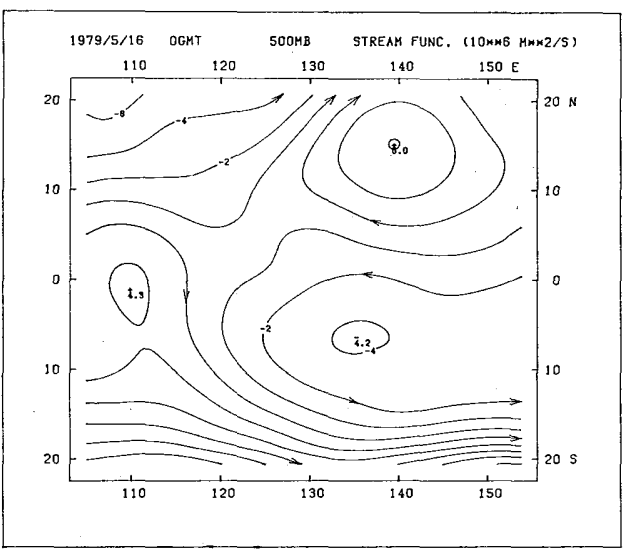

(b)

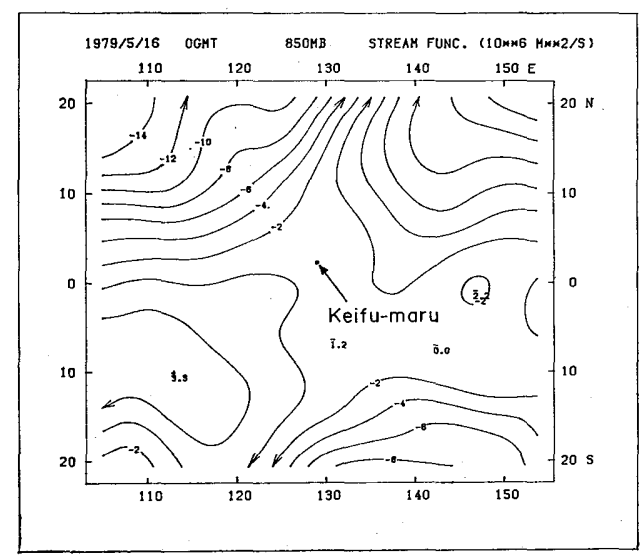

(c)

Fig. 2. Stream function $(\Psi)$ in unit of $10^{6} \times$ $\mathrm{m}^{2} \mathrm{sec}^{-1}$ at (a) $200 \mathrm{mb}$, (b) $500 \mathrm{mb}$ and (c) $850 \mathrm{mb}$ at 00 GMT 16 May 1979.

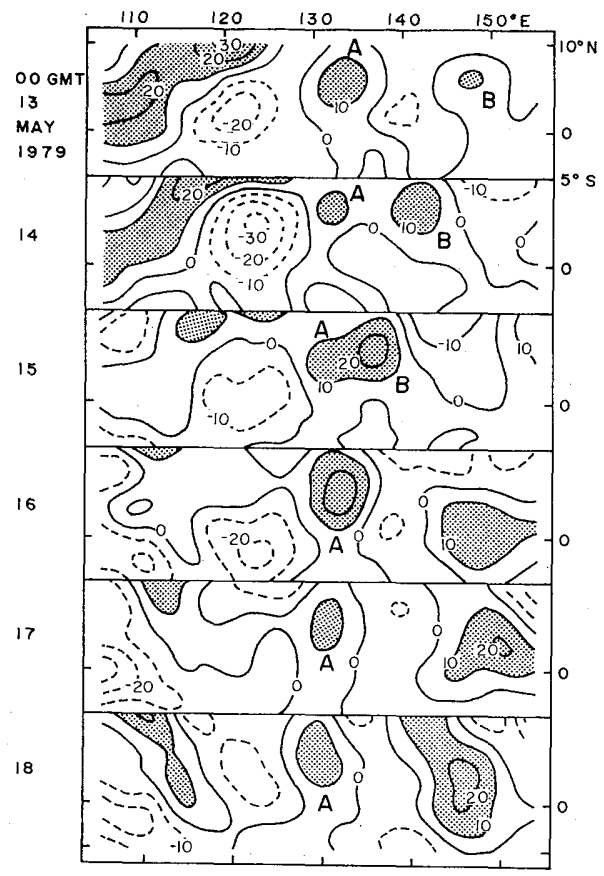

Fig. 3. Sequence of distribution of relative vorticity $(\zeta)$ in unit of $10^{-6} \mathrm{sec}^{-1}$ at $700 \mathrm{mb}$ within the zone between $10^{\circ} \mathrm{N}$ and $5^{\circ} \mathrm{S}$ from 13 to 18 May 1979. Positive areas greater than $10 \times 10^{-6} \mathrm{sec}^{-1}$ are shaded.

$2.6 \times 10^{-5} \mathrm{sec}^{-1}$ on 16 May. The squall line was formed at the southwest part of this region of positive vorticity.

The trough corresponding to positive vorticity region $B$ moved westward in the trade wind that was observed below $500 \mathrm{mb}$. The axis of the trough, which was defined as the position of the maximum of positive vorticity at each pressure level, leaned eastward with height on 13 May, and became vertical on 14 and 15 May. On 16 May, the axis of the trough associated with the merged region of positive vorticity tilted westward with height.

\subsection{Divergence field}

Fig. 4 shows the vertical profiles of horizontal divergence on a 7.5 latitude/longitude square enclosed by the line $a$ in Fig. 1 at 00 GMT on 16 may and of the average during 11 days from 10 to 20 May (the 11-day average). A large divergence of $6 \times 10^{-6} \mathrm{sec}^{-1}$ 


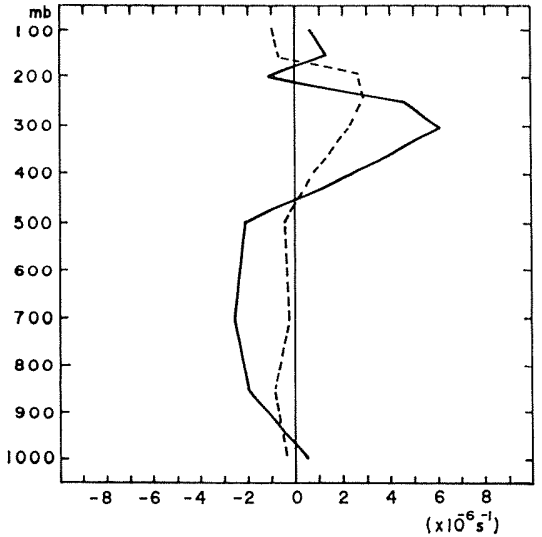

Fig. 4. Vertical profile of horizontal divergence at 00 GMT on 16 May 1979 (solid line), and the mean value during 11 days from 10 to 20 May (dashed line) averaged in the area denoted by $a$ in Fig. 1.

occurred in the upper troposphere, and a moderate convergence of $2 \times 10^{-6} \mathrm{sec}^{-1}$ existed below $450 \mathrm{mb}$ on 16 May, and these values were larger than the average value. Though the divergence in the upper troposphere in our case was somewhat small, the vertical profile of divergence and convergence on 16 May was similar to the results obtained by many investigators (Reed and Recker, 1971; Yanai et al., 1973; Ruprecht and Gray, 1976) in the Western Pacific cloud clusters.

\subsection{Satellite picture}

Fig. 5 shows the sequence of IR satellite pictures. The squall line formed between 03 GMT and 06 GMT on 16 May 1979 at $2^{\circ} \mathrm{N}$ and $129^{\circ} \mathrm{E}$. Before this, only small shallow convections had existed in this region. The cloud mass of the squall line had an area of about $60000 \mathrm{~km}^{2}(300 \mathrm{~km}$ long from east to west and $200 \mathrm{~km}$ long from north to south) at 06 GMT. According to the hierarchy of the horizontal dimension of tropical disturbances after ISMG (1972), this squall line was a rather large one as a mesoscale weather phenomenon.

Radar observation was made aboard the

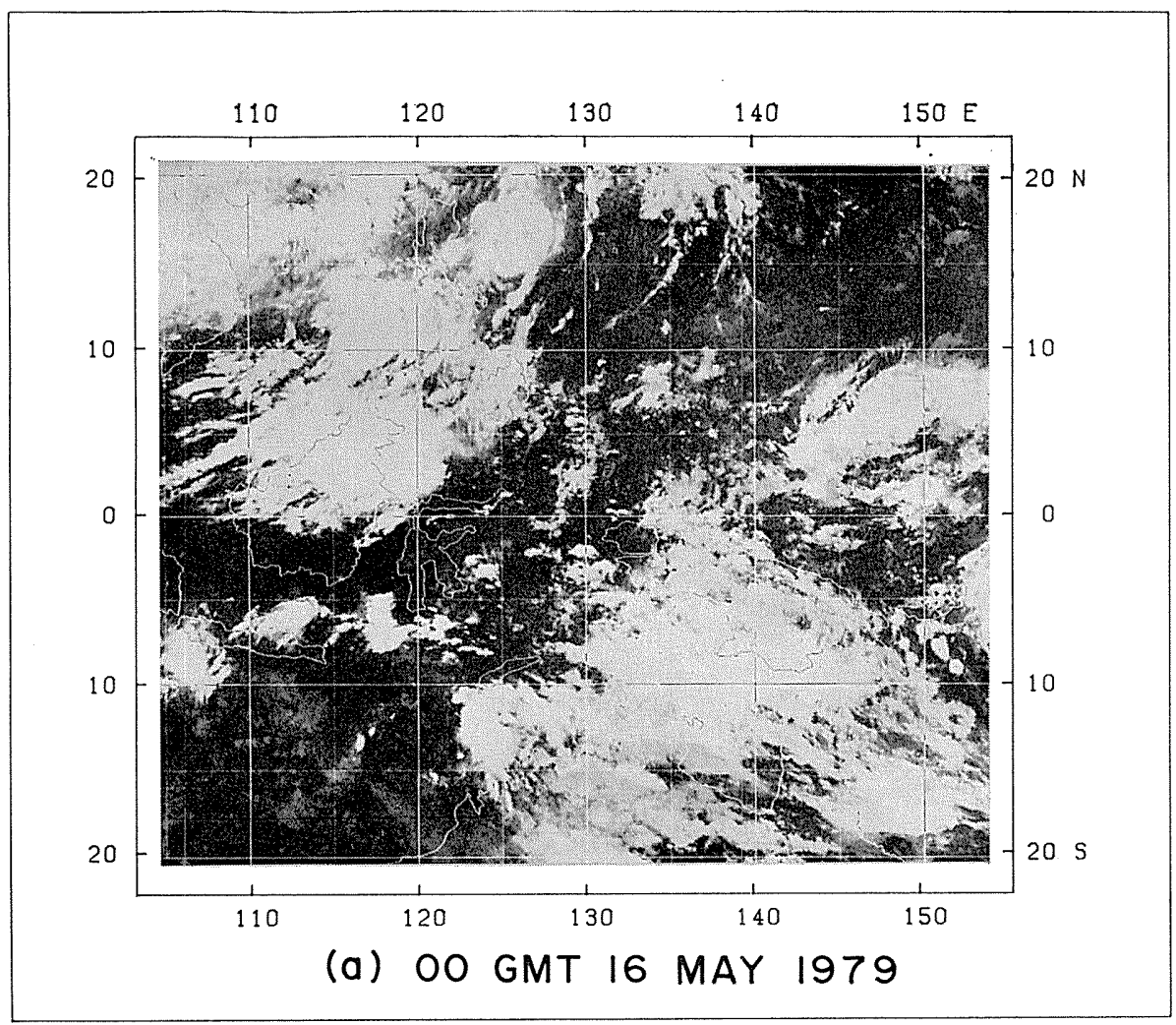



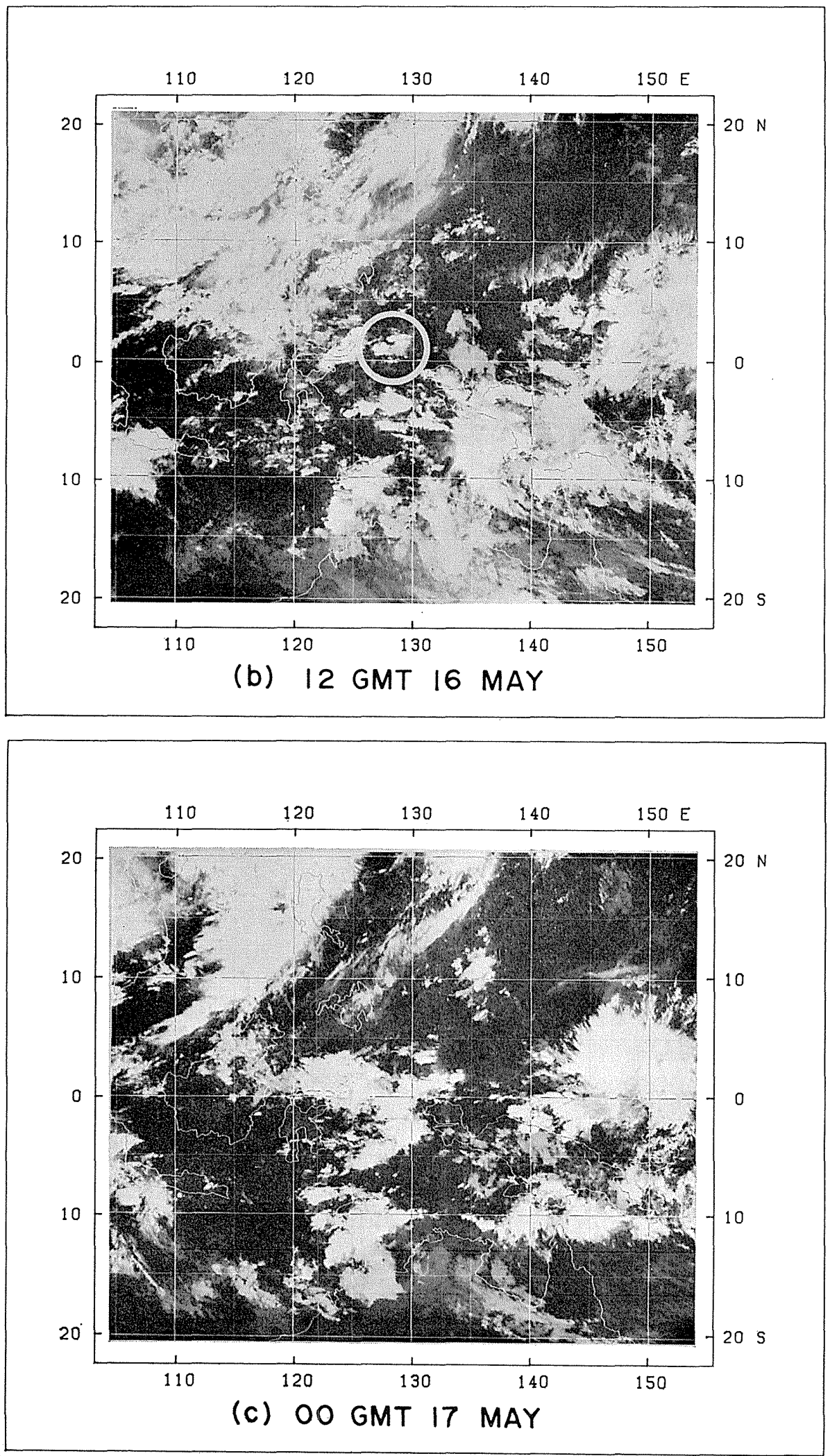

Fig. 5. GMS infrared pictures on 16 and 17 May 1979. Circle in (b) denotes the position of the squall line. 
Keifu-maru for five hours from 08 GMT to 13 GMT on 16 May. Satellite pictures showed that after the end of the radar observation the cloud mass involving the squall line moved eastward and became the northeastern part of a large-scale cloud cluster by 00 GMT on 17 May as shown in Fig. 5-c.

\section{Structure of clouds in the squall line}

In this chapter we discuss the structure of clouds in the squall line. Here the term clouds refers to both non-precipitation clouds and precipitation clouds. The term echoes refers to precipitation clouds detected by radar.

\subsection{Outlook of the squall line}

Fig. 6 shows the sequence of the horizontal distribution of radar echoes nearly every hour, and Fig. 7 shows the horizontal distribution of temperature at the cloud top measured by the GMS IR sensor. As shown in Chapter 3, the squall line was formed between 03 and 06 GMT.

In Fig. 6-a, 6-b, 6-c two leading edges were seen. The northern one (we call it Leading Edge 1, LE. 1) was arc-shaped and
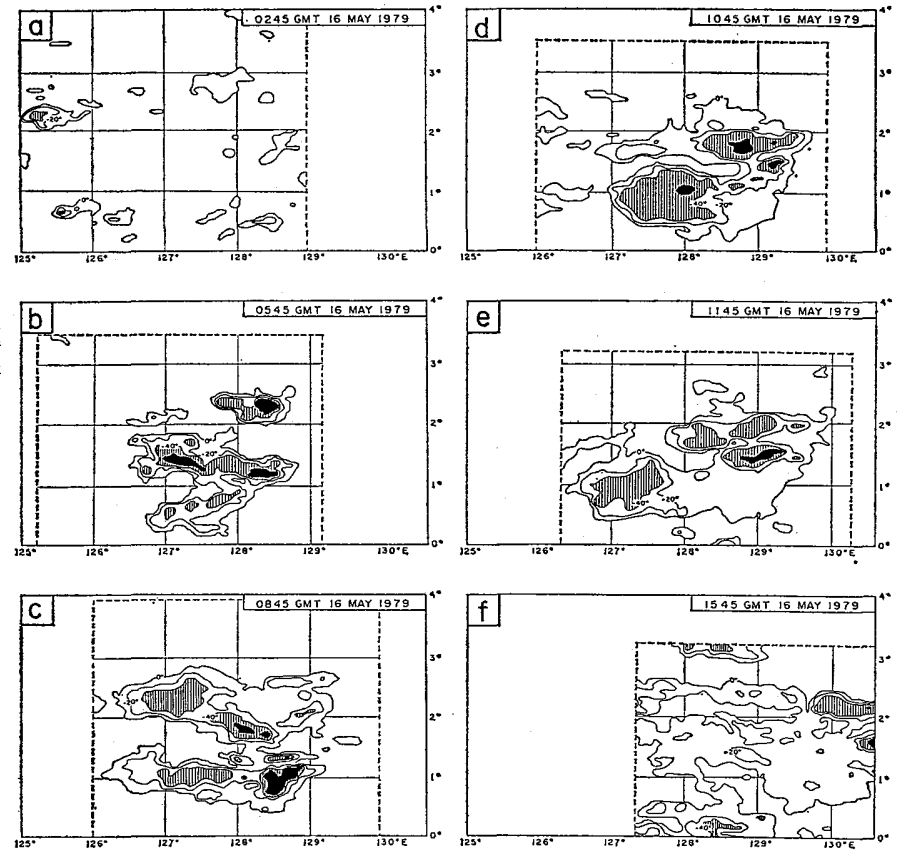
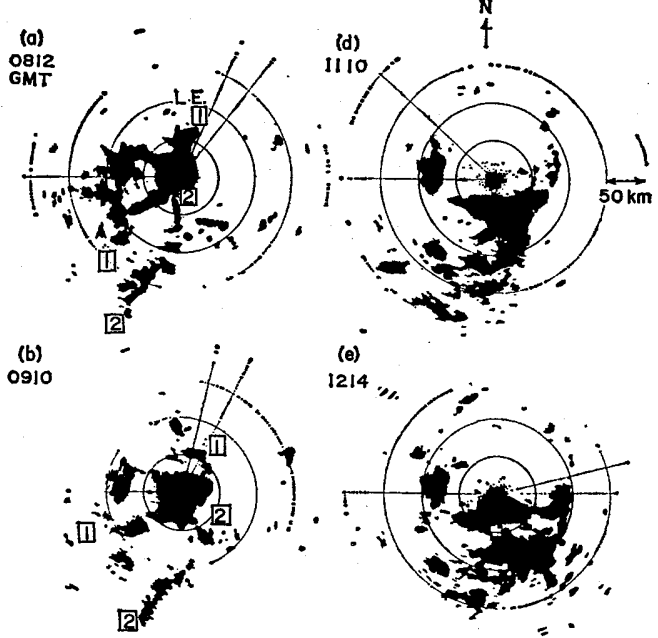

(e)
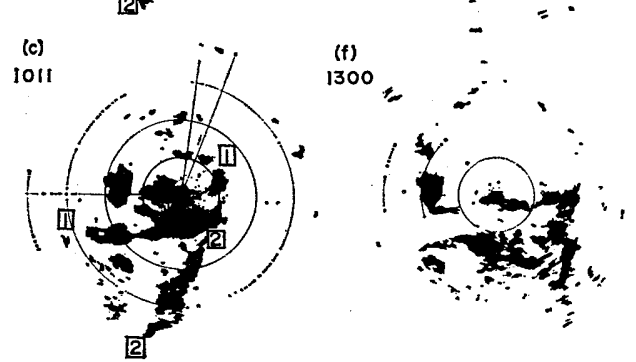

Fig. 6. The evolution of the squall line on PPI of the Keifu-maru radar from 0812 to 1300 CMT on 16 May 1979. Two distinct leading edges are seen till 1011 GMT.
Fig. 7. Sequence of contour maps of cloud top temperature measured by GMS IR radiometer. Contours indicate $0^{\circ} \mathrm{C},-20^{\circ} \mathrm{C},-40^{\circ} \mathrm{C}$ and $-60^{\circ} \mathrm{C}$ outside to inside, respectively. 
about $150 \mathrm{~km}$ long aligned from north to southwest. It passed over the Keifu-maru about 08 GMT. The southern leading edge (LE. 2) was located $30 \mathrm{~km}$ south of the Keifumaru and extended south-southwest (SSW) for about $180 \mathrm{~km}$. LE. 1 moved to ESE and LE. 2 moved almost due east, and they merged into a larger leading edge at about 11 GMT. After the merging it moved to ESE.

The area of radar echo did not appreciably increase with elapse of time, while the area covered by upper level clouds (the area colder than $-40^{\circ} \mathrm{C}$ ) gradually increased till 08 GMT. Fig. 7-c shows that the cloud area higher than $0^{\circ} \mathrm{C}$ level extended over an area about $250 \mathrm{~km}$ wide toward west from the leading edge. At 1545 GMT, 13 hours after the squall line was formed, the total cloud area widely expanded, but the area covered by upper level clouds began to decrease and the boundary between the cloud area and the ambient non-cloud area became ambiguous. The radar observation captured the squall line at growing and mature stages.

\subsection{Movement of the squall line}

Fig. 8 shows the sequential positions of the leading edges. The average moving speed of LE. 1 shown in Fig. 6 or Fig. 5 was $6.3 \mathrm{~m} / \mathrm{s}$ in the direction of $120^{\circ}$, and that of LE. 2 was $4.6 \mathrm{~m} / \mathrm{s}, 90^{\circ}$. After LE. 1 and LE. 2 were merged at about 11 GMT, the leading edge moved toward $120^{\circ}$ at $6.8 \mathrm{~m} / \mathrm{s}$, and the southern part of it corresponding to LE. 2 gradually dissipated.

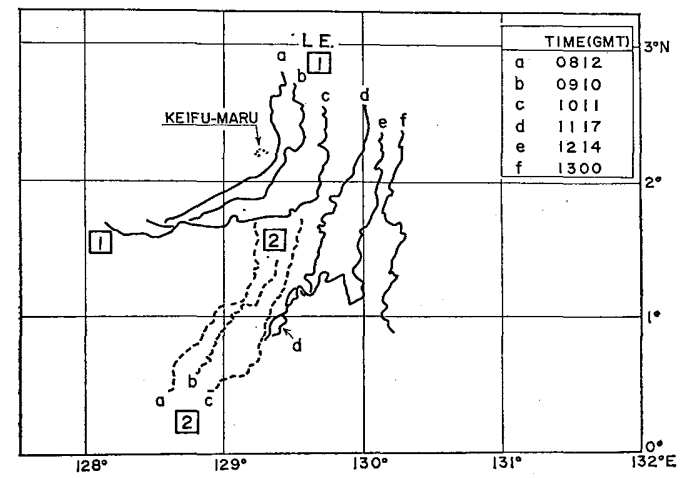

Fig. 8. Advance of two leading edges, LE. I and LE. 2, of the squall line shown in Fig. 6.

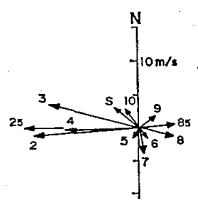

(0) 06 GMT 16 MAY 1979

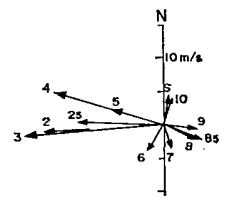

(b) $12 \mathrm{GMT}$

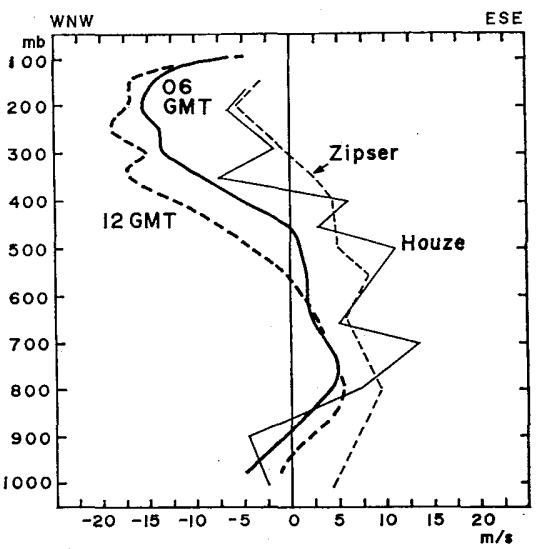

Fig. 9. Hodographs of upper winds obtained on the Kifu-maru and WNW-ESE component of upper winds. The sounding at $06 \mathrm{GMT}$ was made $50 \mathrm{~km}$ ahead of and $90 \mathrm{~km}$ behind the leading edge at 12 GMT. Thin lines show the wind component parallel to the propagating direction of the leading edge presented by Zipser (1977) and Houze (1977).

Fig. 9 shows hodographs before and after the passage of the squall line observed on the Keifu-maru and parallel components of upper winds to the movement direction of LE. 1. LE. 1 moved parallel to the wind at about $800 \mathrm{mb}$. However, the average moving speed of LE. 1 was slightly larger than the wind speed at $800 \mathrm{mb}$. This suggests that the movement of leading edges was occurred by the propagation of echoes. We will discuss the propagation of leading edges in Chapter 8.

\subsection{Classification of radar echoes}

Fig. 10 shows several PPI displays in which the outside contours correspond to echoes detected in gain-level 1 and the inside ones to gain-level 4. Notice that the echo intensity in Fig. 10 is not simply proportional to the rainfall rate because the signal returning from echoes was not range-corrected in 

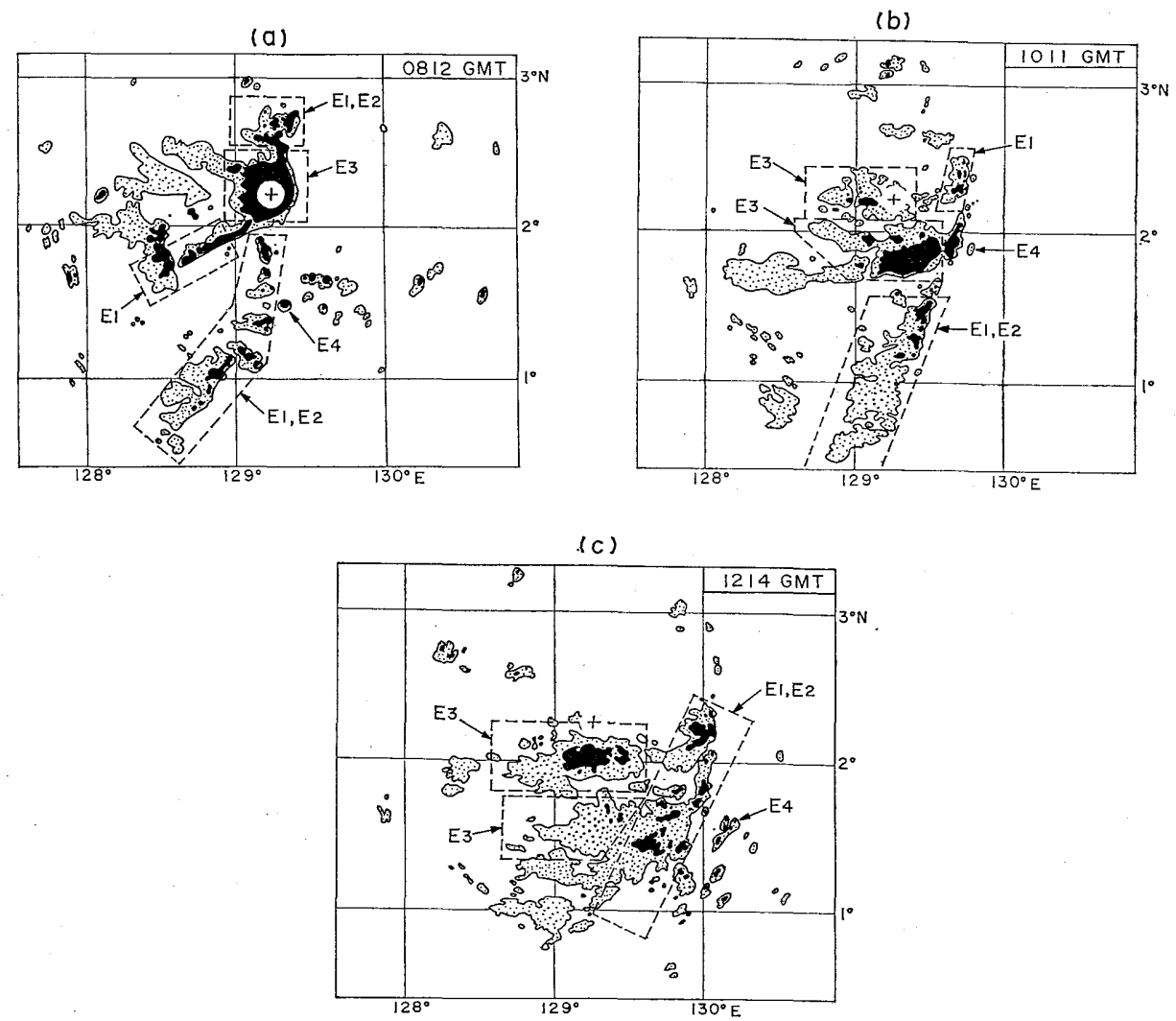

Fig. 10. Classification of radar echoes in the squall line. Areas shaded black show high reflectivity echoes detected in gain-level 4. Data less than $10 \mathrm{~km}$ from the radar site are omitted.

the receiver. Table 2 shows the thresholds of effective radar reflectivity factor $(Z)$ and the rainfall rate $(R)$ corresponding to four gain-levels. $\mathrm{R}$ was calculated from the $\mathrm{Z}-\mathrm{R}$ relationship,

$$
\mathrm{Z}=200 \mathrm{R}^{1.6}
$$

derived by Marshall and Palmer (1948). Fig. 12 shows contours of echo height obtained from the 3-D observation at $0955 \mathrm{GMT}$.

In order to examine the structure of the rain area in the squall line, we classified radar echoes in the squall line into four categories on the basis of type and location of echoes as follows.

1) Echo Area 1 (E1): E1 was the echo area forming leading edges in the fore part of the squall line. It had large echo intensity

Table 2. Relationship between gain-levels of the radar receiver and effective radar reflective factor $(Z)$ corresponding to distance $(r)$. $\operatorname{Pr}$ is the minimum detectable signal corresponding to four gain-levels.

\begin{tabular}{cccccccccc}
\hline Gain & \multirow{2}{*}{$\operatorname{Pr}$} & \multicolumn{2}{c}{$\mathrm{r}=50 \mathrm{~km}$} & \multicolumn{2}{c}{$\mathrm{r}=100 \mathrm{~km}$} & \multicolumn{2}{c}{$\mathrm{r}=150 \mathrm{~km}$} & \multicolumn{2}{c}{$\mathrm{r}=200 \mathrm{~km}$} \\
Level & & $\mathrm{Z}$ & $\mathrm{R}$ & $\mathrm{Z}$ & $\mathrm{R}$ & $\mathrm{Z}$ & $\mathrm{R}$ & $\mathrm{Z}$ & $\mathrm{R}$ \\
\hline 1 & -101 & 10 & 0.2 & 17 & 0.4 & 21 & 0.8 & 25 & 1.3 \\
2 & -93 & 18 & 0.5 & 25 & 1.3 & 29 & 2.5 & 33 & 4.2 \\
3 & -80 & 31 & 3.1 & 38 & 8.5 & 42 & 16. & 46.27. \\
4 & -70 & 40 & 11. & 47 & 31. & 51 & 60. & 55 & 99. \\
\hline
\end{tabular}

$\operatorname{Pr}: \mathrm{dBm}, \quad \mathrm{Z}: \mathrm{dBZ}, \mathrm{R}: \mathrm{mm} / \mathrm{hr}$ 


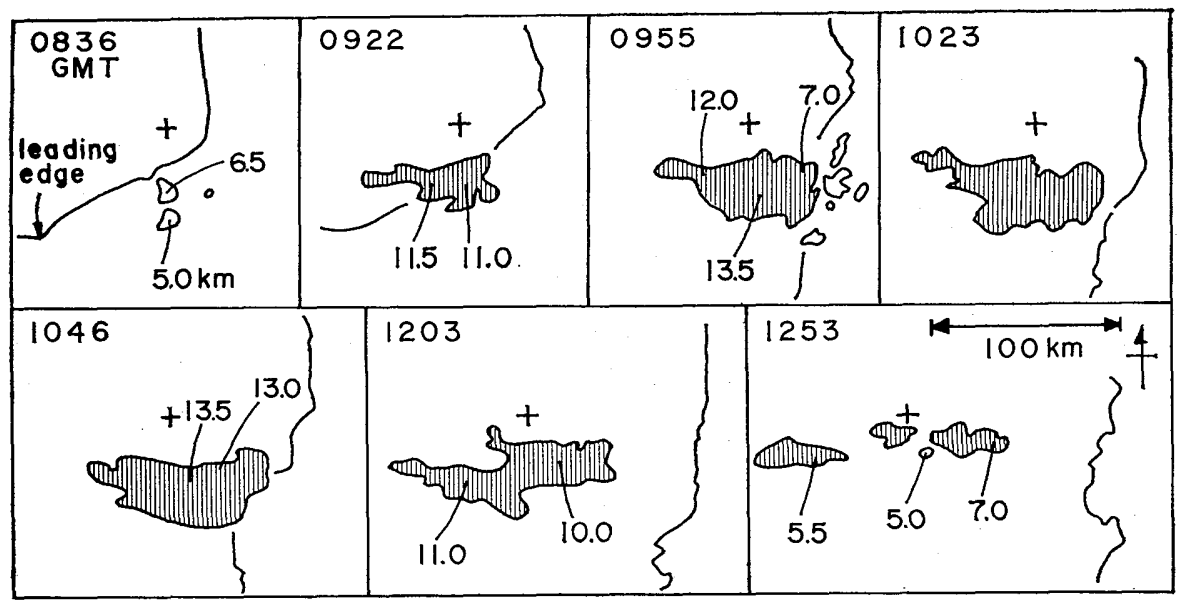

Fig. 11. Evolution of an organized convective echo E3 and its echo height from 0836 to 1253 GMT on 16 May. The position of the Keifu-maru is denoted by '+'.

and included discrete convective cores. These cores had about 10 to $20 \mathrm{~km}$ horizontal dimension and a lifetime of 20 to 30 minutes. The echo height of convective cores was 5 to 10 $\mathrm{km}$, in most cores less than $7 \mathrm{~km}$.

2) Echo Area 2 (E2): Uniform echoes often existed just behind E1. The echo intensity was much smaller than that of E1 (less than about $30 \mathrm{dBZ}$ ) and the echo height was equal to or less than that of $\mathrm{E} 1$.

3) Echo Area 3 (E3): Some convective cores in E1 expanded their area more than ten times, increased echo intensity, and persisted for several hours. We termed this area as an organized convection embedded in the squall line because of its horizontal scale larger than cumulus-scale and its long lifetime. During the observation, three E3's were seen in the squall line. A history of one of them is shown in Fig. 11. It existed just behind the leading edge and reached 100 $\mathrm{km}$ in length and in $50 \mathrm{~km}$ width at 1023 GMT. At $1203 \mathrm{GMT}$ it was positioned $50 \mathrm{~km}$ behind the leading edge and kept echo intensity and areal extension almost as large as at 1023 GMT. Echo height of E3 at the mature stage was more than $13 \mathrm{~km}$. Overhang echoes (or upper echoes) often existed in the rear part of E3 as shown by dashed lines in Fig. 12.

4) Echo Cell 4 (E4): There were fre-

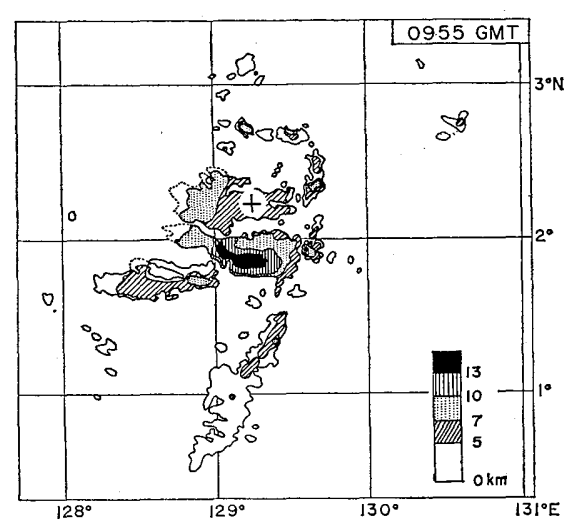

Fig. 12. Distribution of echo height in the squall line obtained from 3-D observation at 0955 GMT on 16 May.

quently found isolated convection cells ahead (east) of the leading edge. They existed apart but not so far from the leading edge (mostly less than about $30 \mathrm{~km}$ from the leading edge), and their intensity sometimes reached as large as that of E1. Echo height was generally less than $5 \mathrm{~km}$.

\subsection{Classification of clouds}

We also classified the clouds in the squall line by use of GMS IR data as follows.

Cloud Area 1 (C1): This cloud area corresponded to $\mathrm{E} 1$, and was located in the leading edge. The height of cloud top of $\mathrm{Cl}$ was 5 to $8 \mathrm{~km}$, and closely accorded with the echo 
height of E1.

Cloud Area 2 (C2): This area included echo area E2, and extended 10 to $150 \mathrm{~km}$ backward (westward) from the rear of $\mathrm{C}$. The height of $\mathrm{C} 2$ ranged from $7 \mathrm{~km}$ to $12 \mathrm{~km}$.

Cloud Area 3 (C3): This area spread out widely toward east and west, especially to west, over the organized convection E3. C3 had a flat cloud top around the convective core that was shown as an intense echo area in E3. The top of the convective cores was more than $13 \mathrm{~km}$ (colder than $-60^{\circ} \mathrm{C}$ ). It was considered that this flat cloud top corresponded to anvil clouds that were produced at the

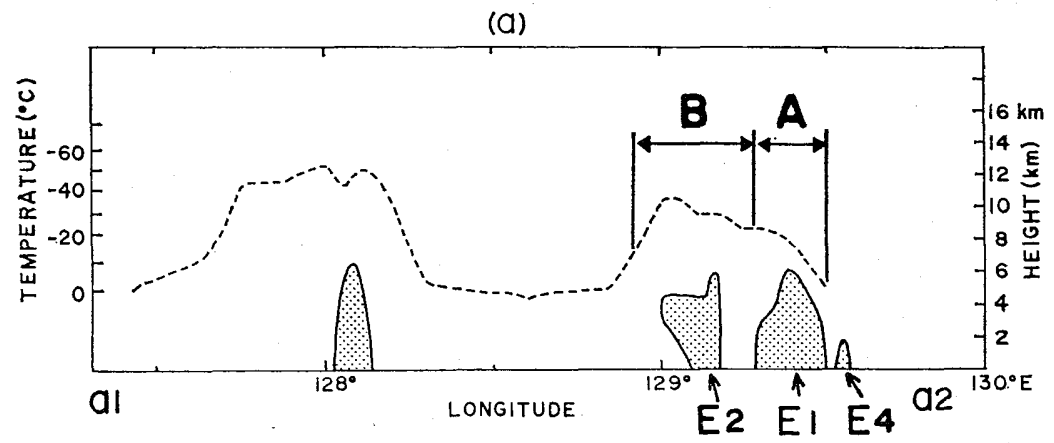

(b)

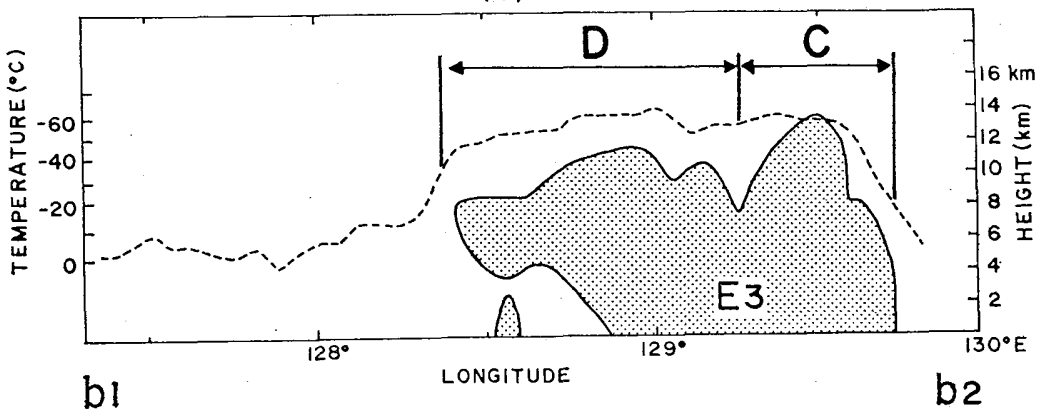

(C)

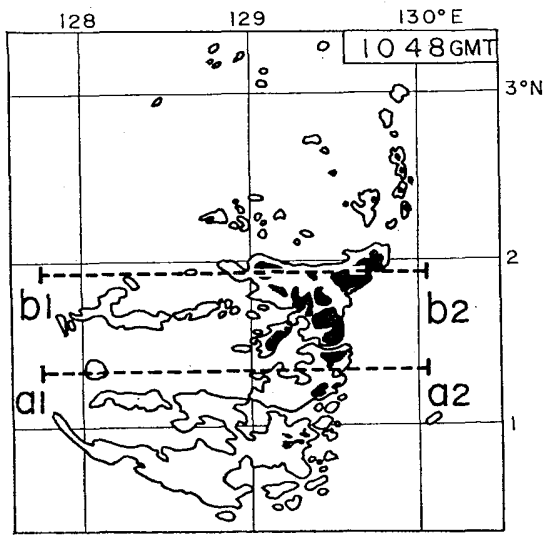

Fig. 13. East-west cross sections of the squall line. Dashed lines indicate the cloud boundary obtained from GMS IR data and shaded areas indicate radar echoes. (a) The area including radar echo E1, E2 and E4. (b) Organized convection C3. (c) Corresponding horizontal echo pattern at 1048 GMT. 
convective core and spread out by the easterly of about $20 \mathrm{~m} / \mathrm{s}$ at about $200 \mathrm{mb}(12.5 \mathrm{~km})$ at 12 GMT.

The clouds corresponding to E4 could not be discriminated on the satellite data because the spatial resolution of the IR sensor on board GMS satellite is equivalent to the size of $\mathrm{E} 4$.

\subsection{Vertical cross-section of clouds}

Fig. 13 shows the vertical cross-section of the clouds containing echo areas E1, E2, E3, E4 and cloud areas C1, C2, C3 at 1048 GMT. The cloud of area A in Fig. 13-a had cellular cores of echo, which had intense reflectivity and a lifetime of about $30 \mathrm{~min}$ utes. This area consisted of cumulus clouds at a growing or mature stage.

The clouds in area $\mathrm{B}$ in Fig. 13-a just behind area $\mathrm{A}$ belonged to category $\mathrm{C} 2$. In this area, radar echoes existed in some cases, and only non-precipitation clouds were found in other cases. The top of clouds in area B observed by the satellite was about $10 \mathrm{~km}$ and it was twice as high as that of radar echoes located under it. Cloud area B gradually expanded rearward (westward) with the elapse of time and reached nearly $70 \%$ of the total cloud area of the squall line at 1300 GMT. Thus, this area consisted of cumulus clouds at the decaying stage accompanied by non-precipitation clouds, that is, altocumulus, cirrus and so on, as reported by the surface weather observation at 12 GMT.

Fig. 13-b shows the vertical cross-section containing organized convection C3. The fore part of it, area C, consisted of a well-developed cumulonimbus. The height of the cloud of area C reached $14 \mathrm{~km}$, and it closely accorded with the height of the echo top. The further apart from the leading edge toward the rear of the squall line, the lower was the height of echo top. The cloud higher than $13 \mathrm{~km}$ expanded rearward as far as 150 $\mathrm{km}$ from the leading edge.

Radar echoes in area $D$ were almost stratiform, and an overhang echo was seen in the rear part of it. Fig. 14 shows the RHI display of the rear part of another organized cloud C3. A bright band was seen beneath the $0^{\circ} \mathrm{C}$ level (about $4.5 \mathrm{~km}$ high). This fact proveded that this portion consisted of stratiform echoes and that a steady rain process was occurring. Therefore, it was concluded that the organized convection $\mathrm{C} 3$ in the squall line was a composition of three types of clouds: (1) well-developed cumulonimbus in the front, (2) stratiform clouds containing a melting snow layer in the rear, and (3) anvil clouds that covered these two precipitation areas. The summary of the classification of clouds and echoes in the squall line is schematically presented in Fig. 15.

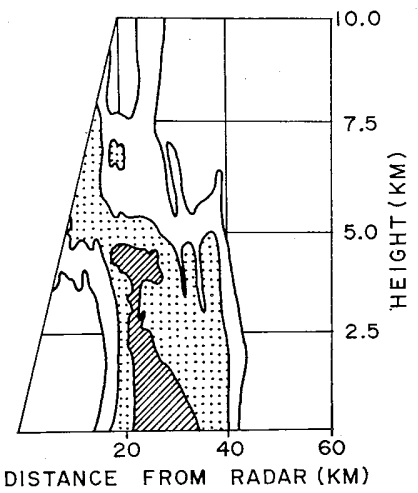

Fig. 14. RHI display along azimith $149^{\circ}$ at 1206 GMT. Contours indicate areas detected in gain-level 1, 3 and 4 from outside to inside respectively.

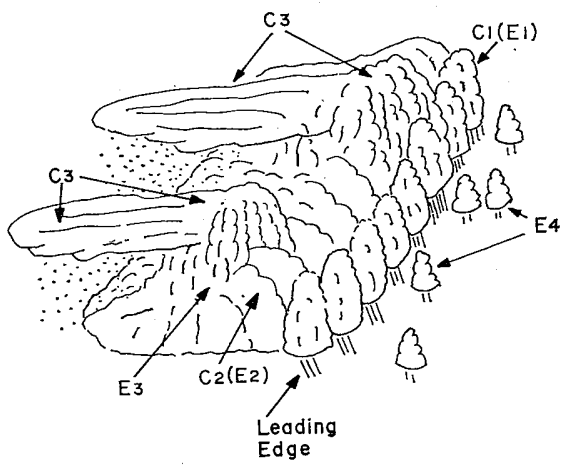

Fig. 15. Schematic view of clouds constituting the squall line.

\section{Change of weather}

\subsection{Changes in the surface weather}

Fig. 16 shows the time series of surface data observed on the Keifu-maru. We devided 
the rainfall period associated with the passage of the squall line into three periods on the basis of rainfall intensity and distribution of raindrops: (1) the first rain period $\mathrm{P} 1$ (0805 to 0827 GMT, total rainfall amount was 0.5 $\mathrm{mm})$, (2) the second rain period $\mathrm{P} 2$ (0827 to $0850,9.5 \mathrm{~mm}$ ), (3) the third rain period $\mathrm{P} 3$ (0900 to 0955, $4.0 \mathrm{~mm}$ ).
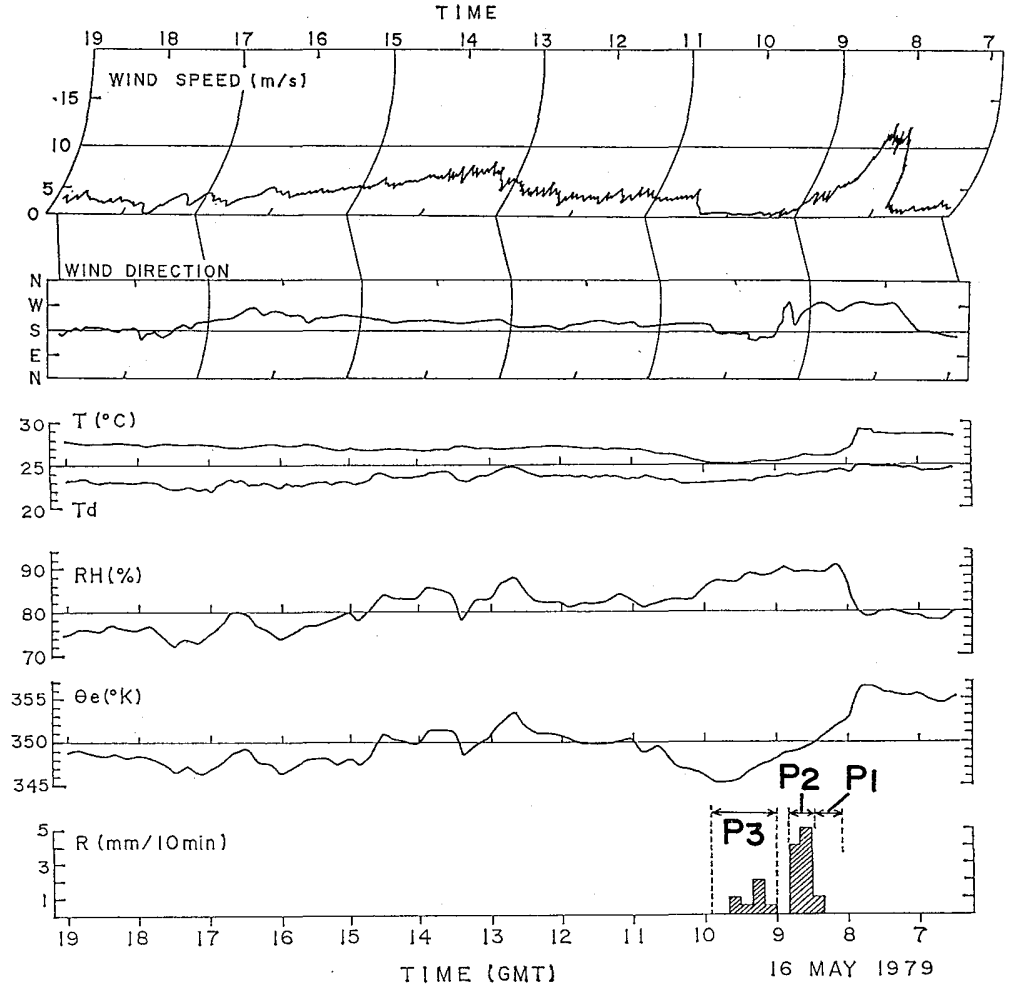

Fig. 16. Temporal variation of wind speed, direction, dry and dew-point temparature (T, Td), relative humidity $(\mathrm{RH})$, equivalent potential temperature $(\theta \mathrm{e})$ and rainfall amount $(\mathrm{R})$ observed on the Keifu-maru on 16 May.
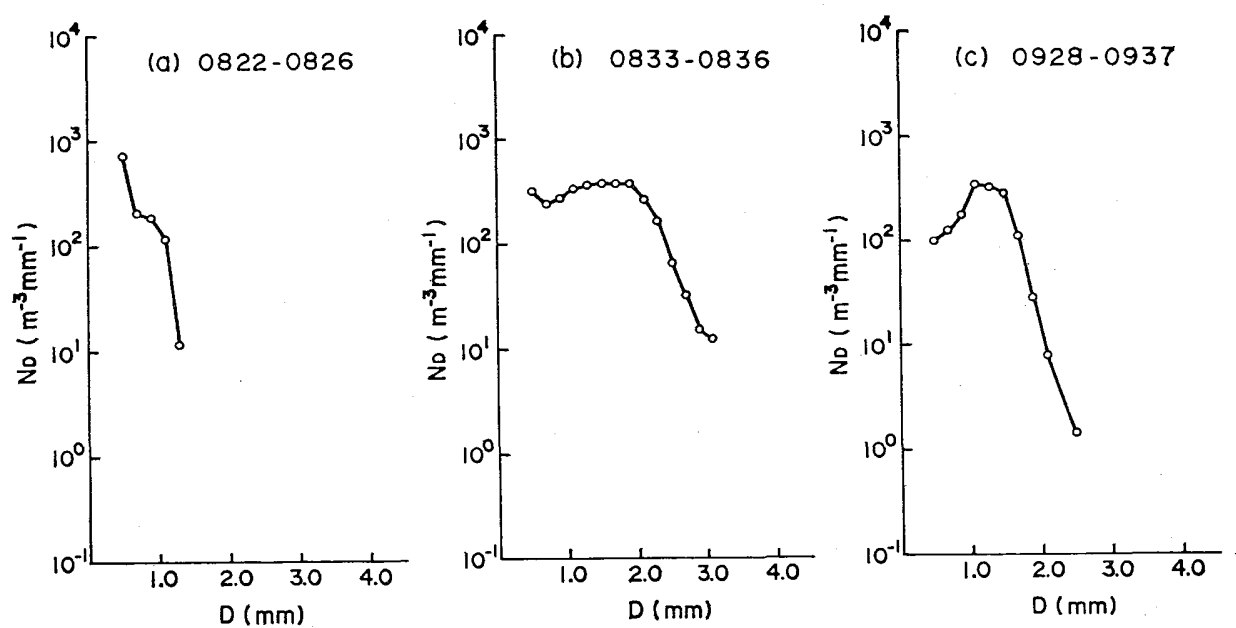

Fig. 17. Size distributiins of raindrops on the passage of the squall line obtained on the Keifu-maru. (a) the first rain period, (b) the second rain period and (c) the third rain period. 
The rain during $\mathrm{P} 1$ came from the clouds located ahead of the leading edge. Fig. 17-a shows the size distribution of raindrops measured on the Kefui-maru in this period. The spectrum of the number of raindrops was very narrow, and the total rainfall amount was small. It was found that the rain in P1 came from shallow cumulus clouds, which corresponded to E4 described in Chapter 4.

During $\mathrm{P} 2$, the size of raindrops was widely distributed from small drops to large ones of more than $3.1 \mathrm{~mm}$ diameter, and the tendency of bi-modal distribution (Fig. 17-b) was seen. The radar echo was intense and higher than $10 \mathrm{~km}$. Rainfall intensity reached $30 \mathrm{~mm}$ per hour. These facts indicate that the rain during $\mathrm{P} 2$ came from cumulonimbus being at the growing or mature stage.

During P3, the size of raindrops was relatively small but the width of the spectrum of the number of raindrops was larger than that observed during P1 (fig. 17-c). The radar echo shows a stratiform pattern, the echo top was about $7.5 \mathrm{~km}$ high, and the rear part of the echo did not reach the surface. Thus, the rain during P3 was originated from the freezing rain that existed below anvil clouds.

Fig. 16 shows that the sudden decrease of dry and dew-point temperature and the sudden increase of relative humidity on the surface occurred at 0749 GMT, which was 16 minutes before the onset of P1. At the same time, gust winds came on, that is, the wind velocity reaching $12 \mathrm{~m} / \mathrm{s}$, and the wind direction shifted from south to west. These weather events associated with the passage of a leading edge are common to squall lines in midlatitudes and tropics.

During the first 20 minutes from 0749 GMT, equivalent potential temperature $\theta e$ dropped 6 degrees, and a slight rain amount (less than $0.5 \mathrm{~mm}$ ) was recorded on the ship. At this time only shallow cumulus existed over the ship, and did not bring about such a strong downdraft that reached the surface. It was thought that this potentially cold air originated from the mid-troposphere air, and that the downdraft embedded in cumulonibus located behind this shallow cumulus brought the air to the surface.

\subsection{Changes in the upper air}

\section{a. Wind}

Fig, 18-a shows the vertical time crosssection for upper winds. At $1000 \mathrm{mb}$, where the wind structure was almost the same as that on the surface, a distinct change of winds was seen. Corresponding to the southeastward movement of the squall line, the wind changed from nearly southeast (SE) before the passage of the squall line to SSW after it. The westerly wind prevailed at 900 and $850 \mathrm{mb}$. At $500 \mathrm{mb}$, a trough of the easterly affected the wind field. The wind changed from NE to ESE. This trough was clearly identified in the pattern of stream function as seen in Fig. 2-b.

A shown in Chapter 3, as far as the middle and lower troposphere was concerned, the observational region was on the south of the boundary of two synoptic-scale flows, that is, the monsoon southwesterly and the trade wind easterly. It was found that the easterly wind prevailed at nearly $500 \mathrm{mb}$ over the Keifu-maru, and that the monsoon southwesterly did below $800 \mathrm{mb}$.

\section{b. Equivalent potential temperature}

Fig. 18-b shows the vertical time crosssection for the deviation of $\theta e$ from the average of $\theta e\left(\theta e^{\prime}\right)$ during 9 to 21 May (the 13-day average) deduced from data obtained from upper sounding and LTS. The profile of $\theta e^{\prime}$ indicates the decreasing of stability in the middle and lower troposphere before the passage of the squall line and the overturning of the atmosphere after it.

The relatively low $\theta e$ air in the middle troposphere between 500 to $800 \mathrm{mb}$ in fig. 18-b was transported both upward and downward between 08 and 24 GMT on 16 May. The large negative layer of $\theta e^{\prime}$ in the middle troposphere ahead of the squall line, the reason for the formation of which is not discussed here, disappeared at 12 GMT. On the contrary, the large negative layer reaching $-8^{\circ} \mathrm{K}$ appeared in the lower level near the surface at $17 \mathrm{GMT}$. After $24 \mathrm{GMT}$ the profile of $\theta e$ began to return to the same condition as the 
(a) WIND

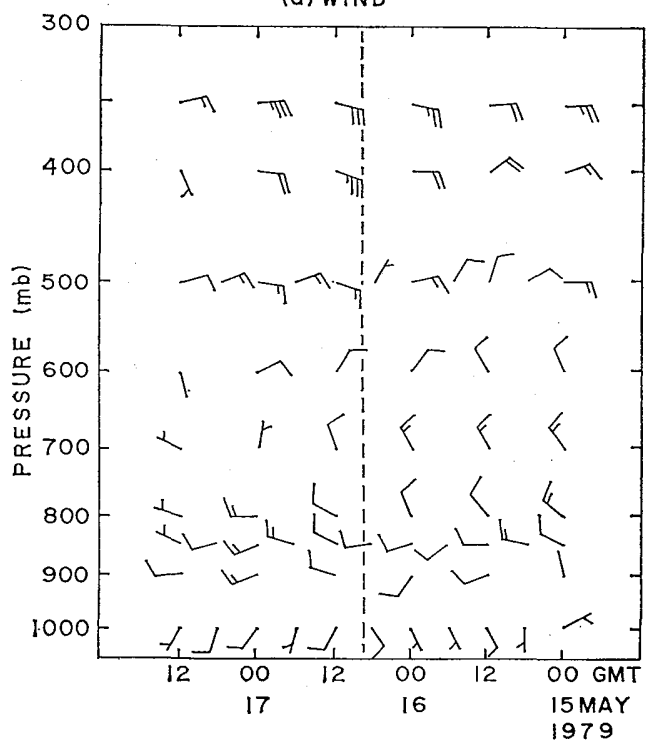

(b) $\theta^{\prime}\left({ }^{\circ} \mathrm{K}\right)$

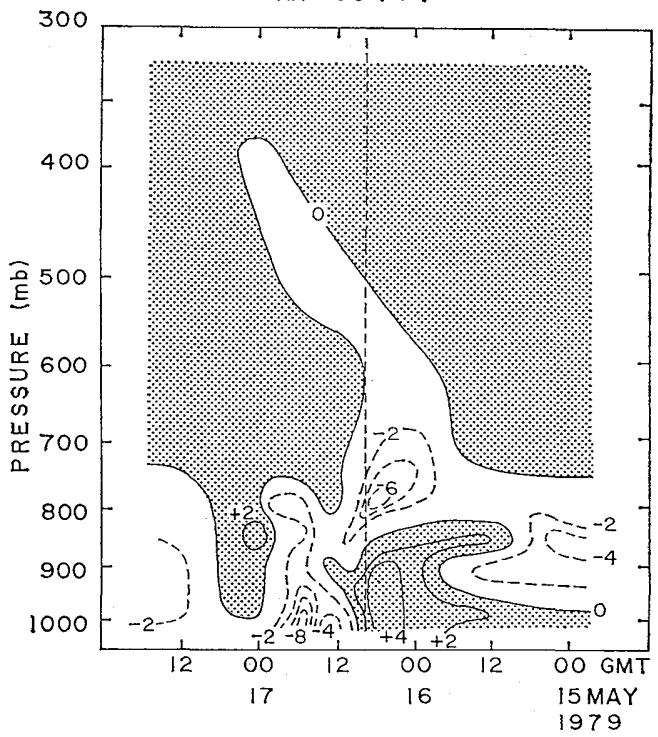

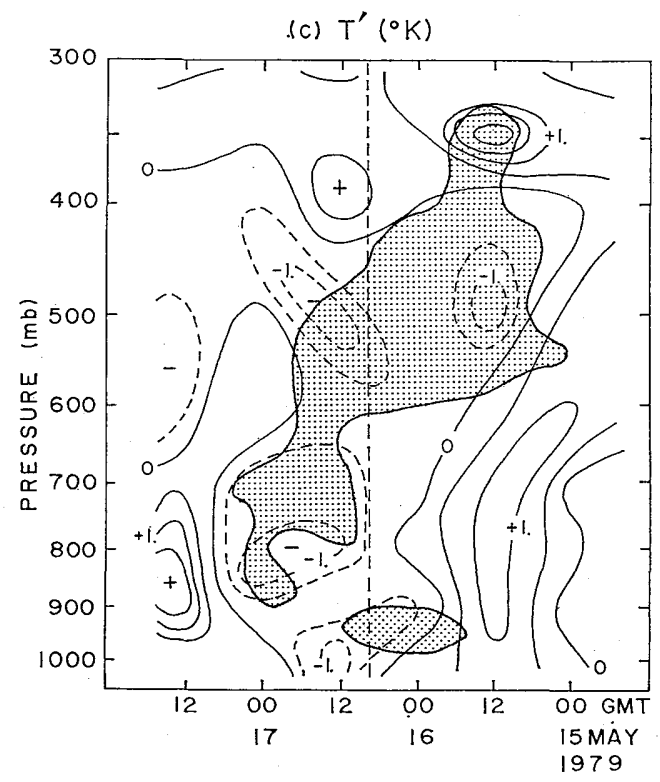

Fig. 18. Vertical time cross-sections of (a) upper winds, (b) deviation from the 13-day average of $\theta e\left(\theta e^{\prime}\right)$, and (c) deviation from the 13-day average of temperature $\left(\mathrm{T}^{\prime}\right)$. Layers with more than $90 \%$ of relative humidity are shaded in (c). Vertical dashed lines show the time of passage of the leading edge.

13-day average:

The positive layer of $\theta e^{\prime}$ of $+4^{\circ} \mathrm{K}$ appeared below $800 \mathrm{mb}$ between 00 and 05 GMT on 16 May, when the squall line was not yet formed. This positive layer resulted from the increase of relative humidity. At the same time, the large-scale convergence of air occurred in the middle and lower troposphere as shown in Fig. 4. This convergence was much larger than the 11-day average. The increase of moisture and convergence of air in the lower troposphere was favorable to 
cumulus-scale convections, and stimulated the formation of a squall line. After the squall line was formed, the moist static energy in this layer was transported upward by the updraft in cumulus or cumulonibus in the leading edge, and supported the growth and maintenance of the squall line.

\section{c. Temperature and humidity}

Fig. 18-c shows the deviation of temperature from the 13-day average from 9 to 21 May. After the passage of the squall line, a cool layer appeared below $450 \mathrm{mb}$. This cool layer was not saturated, but had a large relative humidity of more than $90 \%$. As shown in Fig. 13-b, the uniform cloud and the overhang echo were seen in the rear part of the organized cloud C3. This cool layer was thought to be produced by evaporation of raindrops and melting of ice particles that fall from the upper part of uniform clouds into the ambient unsaturated air below.

\section{Propagation of the squall line}

In this chapter the propagation of echoes that resulted in the large speed of movement of leading edges is discussed. Fig. 19 shows the propagation of the leading edges that were located in the northeastern part of the squall line. This part was composed of convective cells less than $10 \mathrm{~km}$ wide and less than $10 \mathrm{~km}$ high, so that it belonged to E1 and E2 described in Chapter 4.

Leading Edge A (LE. A) in Fig. 19 had already been formed by 0955 GMT, and moved eastward very slowly. At 1011 GMT a new convective cell was generated $4 \mathrm{~km}$ ahead of the leading edge, and moved eastward faster than LE. A. By 1023 GMT four or five cells were formed, and at 1035 GMT they progressed further eastward increasing in size and intensity. By 1117 GMT these cells merged into a line-shaped echo, and a new Leading Edge, LE. B was formed. LE. A stayed and decayed at nearly the same position from 1011 to 1117 GMT. After 1117 GMT LE. B moved eastward and a new Leading Edge LE. C was formed between 1214 and 1230. GMT.

Fig. 20 shows the time variation of the

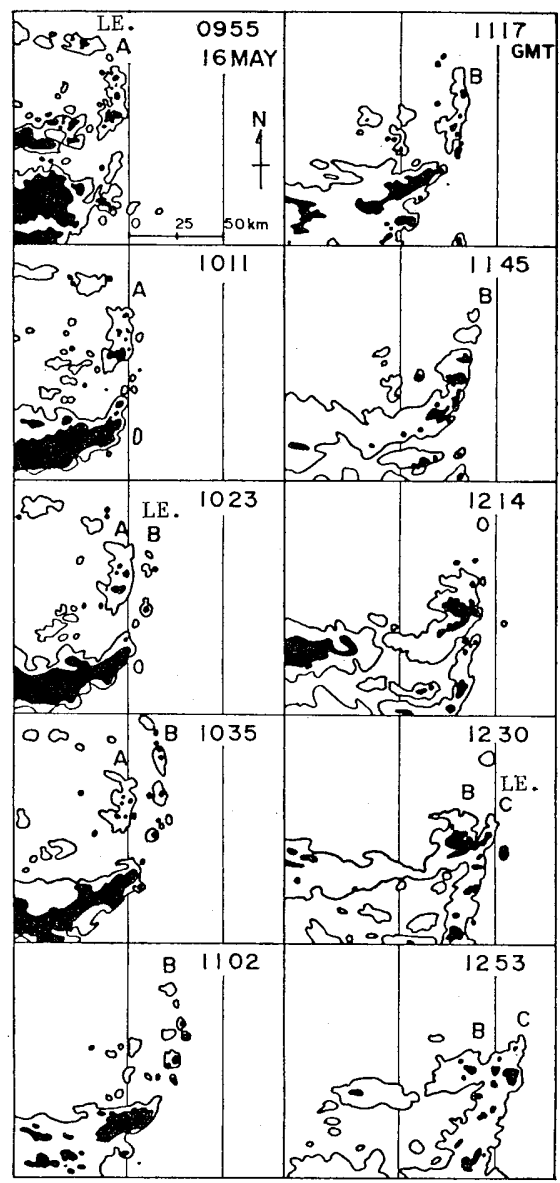

Fig. 19. Propagation of leading edges A, B, C located at the northeastern part of the squall line. The areas shaded black show as Fig. 10.

east-west component of the distance between the Keifu-maru and LE. A, LE. B, and LE. C. Here we define that a new leading edge was formed when one new convective cell was generated ahead of and apart from the pre-existing leading edge. Each leading edge had a lifetime of about 2 hours. The moving speed of a leading edge in the earlier stage was larger than that in the later stage. Particularly once a new cell was generated, the moving speed of the pre-existing leading edge tended to decrease suddenly.

The propagation speed of the group of leading edges was represented by the thin dashed line in Fig. 20. According to it, the east-west component of the propagation speed 


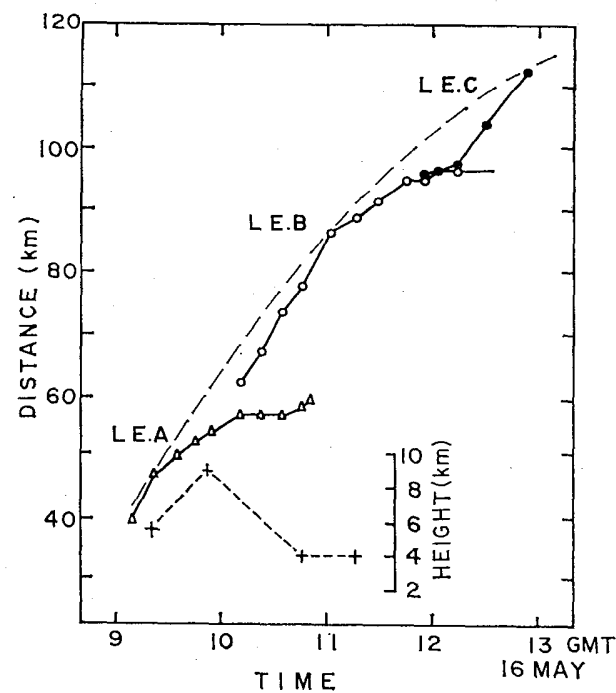

Fig. 20. East-west component of distances between the Keifu-maru and leading edges A, B, C shown in fig. 19. Crosses show the time variation of the eho height of leading edge A. Thin dashed line indicates the propagation of the group of leading edges.

LE. A, LE. B and LE. C was $5.4 \mathrm{~m} / \mathrm{s}$, but the individual leading edge occasionally propagated faster. The propagation speed of LE. B between 1023 and 1035 GMT attained $8.9 \mathrm{~m} / \mathrm{s}$.

The vertical profile of the horizontal wind component parallel to the movement direction of leading edges at 06 GMT on 16 May shown in Fig. 9 was similar to the profile presented by Takeda (1971) as a condition for longlasting convection. The vertical wind shear changed at about $750 \mathrm{mb}$ level.

The propagation of echoes was thought to occur in the following manner. The moist air near the surface ahead of leading edges was carried upward by the updraft in cumulus cloud. Raindrops were produced in the updraft and carried upward. They were carried backward (toward ESE) below $900 \mathrm{mb}$, and obtained horizontal momentum forward (toward ESE) between 900 and $450 \mathrm{mb}$. Raindrops further continued to grow above $450 \mathrm{mb}$ and began to fall due to the increase of size of raindrops. A downdraft was produced by falling raindrops just behind the updraft core. The downdraft air - reached the surface, spread out horizontally, and formed convergence of air with the ambient wind near the surface. This convergence produced a new convective cell ahead of the existing leading edge. If the wind between 900 to $450 \mathrm{mb}$ was small or had a component of opposite direction (toward WNW), the updraft was largely tilted backward and the downdraft was not formed near the updraft core and then no new convective cell was produced ahead of the leading edge.

In the case of organized convection $\mathrm{C} 3$ described in Chapter 4, it started to grow from ordinary cumulus $\mathrm{C} 1$ in its early stage. Once clouds grew into an organized convection $\mathrm{C} 3$ and intense convective cores were formed, C3 persisted for several hours. After new leading edges were formed ahead of C3, the intense convective cores in $\mathrm{C} 3$ were almost stationary.

\section{Comparison with other tropical squall lines}

The structure of tropical squall lines has been investigated by some authors as described in Chapter 1. In this chapter, we compare the structure and properties of the squall line in our case with those of other tropical squall lines.

\section{a. Synoptic situation}

The tropical squall line observed by Houze (1977) in the east Atlantic during GATE was positioned at nearly $10^{\circ} \mathrm{N}$ latitude and was associated with the synoptic-scale African wave. The squall line was positioned ahead of (west of) the trough and behind (east of) the ridge at $700 \mathrm{mb}$ in the wave. Payne and McGarry (1977) obtained the same result from the satellite and wind data during GATE. The synoptic situation of our experimental region was fairly complicated as described in Chapter 3 , but the formation of a squall line was thought to be related to the trough of the trade wind easterly. The positive relative vorticity at $700 \mathrm{mb}$ existed almost stationary in the experimental region, and was strengthened by the trough in the trade wind coming from east just before the tropical squall line 
was formed. The relationship between the formation of squall line and the synopticscale wave was the same both in the Atlantic and our region.

\section{b. Horizontal dimension}

It is of some interest to examine whether tropical squall lines have an inherent horizontal dimension. The maximum rain area of the squall line in our case estimated from the radar PPI data was about $2 \times 10^{4} \mathrm{~km}^{2}$, and those of squall lines observed Zipser (1977) and Houze (1977) were $10^{4}$ and $6 \times 10^{4} \mathrm{~km}^{2}$, respectively. Betts et al. (1976) reported that the mean length of six squall lines observed in Venezuela during VIMHEX-1972 was $98 \mathrm{~km}$. There were some differences in instrumentation, but it was thought that the rain area in tropical squall lines has the order of $10^{4}$ $\mathrm{km}^{2}$ and the horizontal length of the leading edge is in the range of 100 to $200 \mathrm{~km}$.

\section{c. Cloud structure}

Houze (1977) and Zipser (1977) reported that the leading edge consisted of well-developed cumulonimbus, but the leading edge in our case was an aggregate of cumulus lower than $10 \mathrm{~km}$ high. The most characteristic feature of the squall line in our case was the existence of the organized convections ( $\mathrm{C} 3$ described in Chapter 4), which may be called 'super-cell convections'. The organized convections were the most active portions of convection in the squall line. They were formed at the leading edge and continued to live in spite of being left behind the leading edge. Houze and Zipser discussed the structure of squall lines assuming its two-dimensionality. The whole system of the squall line in our case should be regarded as a three-dimensional system, though the leading edge had a two-dimensional structure.

\section{d. Propagation speed}

The propagation speed of the leading edge in our case was about $7 \mathrm{~m} / \mathrm{s}$, and was smaller than that of other tropical squall lines. The propagation speed is thought to depend on the vertical profile of wind and the thermodynamical condition in the lower troposphere. Fig. 9 indicates that wind components parallel to the propagating direction of the leading edge show a profile common to our case and cases of Zipser and Houze. But, the wind speed in the lower troposphere in our case was smaller than those of Zipser and Houze. The wind speed in the troposphere seemed to be largely related to the propagation speed. In our case, the propagation speed was slightly larger than that of the wind at $800 \mathrm{mb}$ observed ahead of the leading edge.

\section{Conclusion}

During the Summer MONEX in 1979 a tropical squall line passed over the observation ship Keifu-maru in the western tropical Pacific. An analysis of the structure of the squall line was made by use of radar, satellite and upper sounding data. The results of the analysis were compared with the structure of tropical squall lines observed by other authors.

The formation of the squall line was thought to be related to the synoptic-scale wave in the trade wind easterly in the middle and lower troposphere, as the squall line observed in the east Atlantic was found in the African wave.

The coexistence of cumulus-scale convections and organized convections was a particular feature of this squall line, so that the structure of the squall line in our case had to be discussed three-dimensionally. The leading edge propagated parallel to the ambient wind at $800 \mathrm{mb}$ at a slightly larger speed than the wind speed.

A denser observation network is necessary to discuss how the organized convection was formed selectively from ordinary $\mathrm{Cu}$ at the leading edge and was maintained for several hours. The core of C3 was welldeveloped $\mathrm{Cb}$, and such $\mathrm{Cb}$ could not be produced in the same way as the ordinary $\mathrm{Cu}$.

Acknowledgements:-The authors thank Dr. M. Fujiwara who gave us the opportunity to participate in this experiment. We also wish to thank all the crew of the Keifu-maru for their help, in particular Y. Mori, H. Matsumoto, and I. Miyashita. The data obtained 
from the lower tropospheric sonde were provided by S. Otsuka. The GMS satellite data were processed by use of software developed by $T$. Inoue of the Meteorological Research Institute and by K. Nakamura and K. Sugimoto, staff members of the Meteorological Satellite Center of Japan. FGGE level III-B data sets were provided by Dr. M. Kanamitsu of the Japan Meteorological Agency. Contours in Fig. 2 were drawn using the program PLOTMA made by Dr. Y. Masuda.

\section{References}

Betts, A.K., R.W. Grover, and M.W. Moncrieff, 1976: Structure and motion of tropical squalllines over Venezuela. Quart. J. Roy. Meteor. soc., 102, 395-404.

Hamilton, R. A., and J.W. Archbold, 1945: Meteorology of Nigeria and adjacent territory. Quart. J. Roy. Meteor. Soc., 71, 231-262.

Houze, R.A., Jr., 1977: Structure the dynamics of a tropical squall-line system. Mon. Wea. Rev., 105, 1540-1567.

ISMG (Interim Scientific and Management Group). 1972: Experiment designp roposal for the GARP Atlantic Tropical Experiment. GATE Rep. No. 1., WMO-ICSU. Geneva, 188 pp.

Marshall, J.S., and W.M. Palmer, 1948: The distribution of raindrops with size. J. Meteor., $5,165-166$.

Ogura, Y., and M.-T. Liou, 1980: The structure of a midlatitude squall line: A case study. J. Atmos. Sci., 37, 553-567.

Payne, S.W., and M. M. McGarry, 1977: The relationship of satellite inferred convective activity to easterly waves over West Africa and the adjacent ocean during phae III of GATE. Mon. Wea. Raa., 105, 413-420.

Reed, R. J., and E.E., Recker, 1971: Structure and properties of synoptic-scale wave disturbances in the equatorial western Pacific. J. Atmos. Sci., 28, 1117-1133.

Ruprecht, E., and W.M. Gray, 1976: Analysis of satellite-observed tropical cloud clusters. 1. Wind and dynamic fields. Tells, XXVIII, 391413.

Takeda, T., 1971: Numerical simulation of a precipitating convective cloud : the formation of a "long-lasting" cloud. J. Atmos. Sci, 28, 350376.

Yanai, M., and T. Nitta, 1967: Computation of vertical motion and vorticity budget in a Caribbean easterly wave. J. Meteor. Soc. Japan, 45, 444-466.

Yanai, M., S. Esbensen, and J.-H. Chu, 1973: Determination of bulk properties of tropical cloud clusters from large-scale heat and moisture budgets. J. Atmos. Sci., 30, 611-627.

Zipser, E. J., 1969: The role of organized unsaturated convective downdrafts in the structure and rapid decay of an equatorial disturbance. J. Appl. Met., 8, 799-814.

Zipser, E. J., 1977: Mesoscale and convective-scale downdrafts as distinct components of squallline circulation. Mon. Wea. Rev., 105, 15681589.

\section{MONEX 期間中西太平洋に発生した熱帯スコールラインの構造}

\section{石原正仁・柳沢善次}

1979 年の Summer MONEX 期間中に, 西太平洋熱帯海洋上に発生した熱帯スコールラインの構造を, レーダー, 衛星, ゾンデデータを使って解析した。解析結果は他の地域で観測された熱帯スコールラインと比較された。

このスコールラインは積雲スケールの対流と, 組織化された対流が複合された内部構造を持ち, anvil 雲が leading edge から後方へ約 $200 \mathrm{~km}$ まで延びていた。この組織化された対流の存在がこのスコールラインの特徵であ った。線状の leading edge 性周囲の風速より大きい速度で伝播した。 leading edge の西る部分は成長して組織 化された対流となり大きさと強度を数時間にわたって維持した。

このスコールラインは, 対流圈下層について見れば, 南西 monsoon と貿易風東風の境界域に発生した。スコー ルラインが発生する直前には, 対流圏中下層にかなり強い正洞度が, $400 \mathrm{mb}$ より上では強い発散が, またそれよ り下層では収束が市った。ゾンデデータはスコールラインの通過伴う大気の転倒を示していた。スコールライン 前方の対流圈下層に存在した moist static energy が，スコールライン形成のエネルギー源であったと考学られ る。

他の地域で観測された熱帯スコールラインと比較して共通点が多かった。組織化された対流の存在のため，この スコールラインの雲構造は 3 次元性の強いものだった。 